\title{
Endocytic pH regulates cell surface localization of glycolipid antigen loaded CD1d complexes
}

\author{
Pooja Arora ${ }^{1,5}$, Shalu S. Kharkwal ${ }^{1,5}$, Tony W. Ng$^{1}$, Shajo Kunnath-Velayudhan ${ }^{1}$, Neeraj K. \\ Saini ${ }^{1}$, Christopher T. Johndrow ${ }^{1}$, Young-tae Chang ${ }^{3}$, Gurdyal S. Besra ${ }^{4}$, and Steven A. \\ Porcelli ${ }^{1,2}$ \\ ${ }^{1}$ Department of Microbiology and Immunology, Albert Einstein College of Medicine, Bronx, NY \\ 10461, USA \\ ${ }^{2}$ Department of Medicine, Albert Einstein College of Medicine, Bronx, NY 10461, USA \\ ${ }^{3}$ Department of Chemistry and NUS Medchem Program of The Life Sciences Institute, National \\ University of Singapore. Singapore 117543 \\ ${ }^{4}$ School of Biosciences, University of Birmingham, Edgbaston, Birmingham B15 2TT, United \\ Kingdom
}

\section{Abstract}

\begin{abstract}
Invariant natural killer T (iNKT) cells recognize glycolipid antigens presented by CD1d, an antigen presenting protein structurally similar to MHC class I. Stimulation of iNKT cells by glycolipid antigens can induce strong immune responses in vivo, with rapid production of a wide variety of cytokines including those classically associated with either T helper type 1 (Th1) or type 2 (Th2) responses. Alterations in the lipid tails or other portions of CD1d-presented glycolipid ligands can bias the iNKT response towards production of predominantly Th1 or Th2 associated cytokines. However, the mechanism accounting for this structure-activity relationship remains controversial. The Th1-biasing glycolipids have been found to consistently form complexes with CD1d that preferentially localize to plasma membrane cholesterol rich microdomains (lipid rafts), whereas CD1d complexes formed with Th2-biasing ligands are excluded from these microdomains. Here we show that neutralization of endosomal $\mathrm{pH}$ enhanced localization of CD1d complexes containing Th2-biasing glycolipids to plasma membrane lipid rafts of antigen presenting cells (APC). Transfer of APCs presenting these "stabilized" CD1d/aGC complexes into mice resulted in immune responses with a more prominent Th1-like bias, characterized by increased NK cell transactivation and interferon- $\gamma$ production. These findings support a model in which low endosomal $\mathrm{pH}$ controls stability and lipid raft localization of CD1d-glycolipid complexes to regulate the outcome of iNKT cell mediated responses.
\end{abstract}

\footnotetext{
${ }_{5}^{\S}$ Correspondence: steven.porcelli@einstein.yu.edu. Tel: (718) 430-3228. FAX: (718), 430-8711.

5 Authors contributed equally to this work.

Publisher's Disclaimer: This is a PDF file of an unedited manuscript that has been accepted for publication. As a service to our customers we are providing this early version of the manuscript. The manuscript will undergo copyediting, typesetting, and review of the resulting proof before it is published in its final citable form. Please note that during the production process errors may be discovered which could affect the content, and all legal disclaimers that apply to the journal pertain.

Disclosures: The authors declare that they have no competing financial interests.
} 


\section{Keywords}

CD1d; aGC; NKT cells; glycolipid; antigen presentation; NK activation; transactivation; IFN $\gamma$ secretion; dendritic cells; endosomal presentation; endosomal pH; pH Neutralization

\section{Introduction}

Invariant natural killer $\mathrm{T}$ cells (iNKT cells) are a subset of $\mathrm{T}$ cells that also express various surface markers more typically associated with natural killer (NK) cells ${ }^{1}$. They are referred to as "invariant" because of the unusual structure of their T cell antigen receptors (TCRs), which are comprised of an invariant TCRa chain associated with TCR $\beta$ chains that also have limited diversity ${ }^{2}$. These cells recognize and respond to glycolipid antigens presented in the context of CD1d, an antigen presenting molecule similar in overall structure to major histocompatibility complex (MHC) encoded class I proteins ${ }^{3}$. Unlike classical $\mathrm{T}$ cells that initially exist in a naïve state that must undergo antigen induced activation and differentiation to become effector or memory cells, iNKT cells leave the thymus as a preprogrammed effector population ${ }^{3 a}$. In addition, reporter mice developed to study IL-4 and IFN $\gamma$ gene expression reveal that iNKT cells contain pre-formed mRNA transcripts for both of these cytokines, and start synthesizing and secreting cytokines within minutes of TCR engagement ${ }^{4}$. This capability to respond rapidly and without prior antigen immunization makes this subset of $\mathrm{T}$ cells an attractive target for various approaches to immunotherapy or immunomodulation ${ }^{5}$.

A large number of natural and synthetic glycolipid antigens that are presented by CD1d to iNKT cells have been described ${ }^{6}$. A common feature of most of these antigens is that they are composed of two lipid tails linked to a carbohydrate moiety or "head group" 7 . The best characterized of these antigens is a synthetic a-galactosylceramide with a long (C26) saturated acyl chain, initially designated as KRN7000 and also commonly referred to aGC $\mathrm{C} 26: 0^{8}$. Depending on the structure of the glycolipid antigen, iNKT cell stimulation may also be followed by the secondary stimulation or transactivation of bystander immune cells such as natural killer (NK) cells, B cells and additional subsets of T cells ${ }^{9}$. Agonists that fail to transactivate other types of leukocytes, especially NK cells, result in the secretion of higher amounts of serum IL-4 compared to IFN $\gamma$, and are called Th2-biasing agonists ${ }^{10}$. In contrast, agonists that strongly transactivate NK cells greatly amplify and prolong the accumulation of serum IFN $\gamma$, and these are often referred to as Th1-biasing agonists.

The mechanisms accounting for the different stimulatory activities of Th1- and Th2-biasing agonists are not completely understood, although several important correlations and potential mechanisms have been documented. For example, most and possibly all Th2biasing agonists contain features that are likely to increase their aqueous solubility compared to the prototypical a-GC C26:0 compound. Such features include truncation of the sphingoid or acyl chain moieties, or introduction of double bonds at one or multiple locations in the lipid chain or other polar groups $10 \mathrm{c}, 11$. Conversely, Th1-biasing agonists are relatively more hydrophobic than a-GC C26:0, and are generated by removal of polar groups. This includes substitution of the O-glycosidic linkage by a C-glycoside, removal of 
hydroxyl groups or replacement of the monosaccharide head group with a carba-sugar analog $6 \mathrm{a}, 11 \mathrm{~b}, 12$.

Several studies using the monoclonal antibody L363, which specifically recognizes mouse $\mathrm{CD} 1 \mathrm{~d} / \mathrm{aGC}$ complexes $10 \mathrm{~b}, 13$, have revealed major differences in the site of formation, trafficking and cell surface localization of these complexes $8 \mathrm{a}, 11 \mathrm{~b}, 14$. In general, complexes containing Th1-biasing glycolipids are formed primarily in endocytic compartments in which the $\mathrm{pH}$ ranges from approximately 4.9 to $6.0^{15}$, and require assistance from lipid exchange proteins such as saposins for formation of complexes with CD1d ${ }^{16}$. Following transport to the cell surface, these complexes localize predominantly to cholesterol rich microdomains, usually referred as lipid rafts, in the plasma membrane ${ }^{8 a, 11 b}$. These microdomains are enriched in GPI-linked and signal transduction proteins, and are believed to act as signaling platforms ${ }^{17}$.

In general, strong localization to lipid rafts of the complexes formed between CD1d and a particular glycolipid antigen is predictive of an increase in the Th1-bias resulting from iNKT cell stimulation. Presentation by lipid raft-localized CD1d results in the upregulation of costimulatory molecules on the surface of CD8a ${ }^{\mathrm{Pos}}$ dendritic cells, the principal professional antigen presenting cell (APC) for glycolipid antigens ${ }^{8 b}$. The increase in costimulatory molecules correlates with higher transactivation of bystander cells such as NK cells, although the detailed mechanism remains unknown. In marked contrast to Th1-biasing glycolipids, the binding of Th2-biasing glycolipids to CD1d occurs predominantly on the cell surface, and the complexes formed are not localized in lipid rafts. Exclusion of these complexes from plasma membrane lipid rafts results in the upregulation of coinhibitory molecules on such as PD-L1 and PD-L2 on the surface of glycolipid APCs. Of note, both of these co-inhibitory molecules are known to prohibit synapse formation between leukocytes ${ }^{18}$ and probably limit transactivation of bystander cells including NK cells, thus culminating in a "pure" iNKT responses characterized by a prominent Th2 cytokine bias.

Complexes of CD1d bound with Th2-agonist glycolipids are not normally detectable in endosomal compartments. However, neutralization of endosomal $\mathrm{pH}$ leads to their rapid accumulation in endosomes, consistent with an ability of low endosomal $\mathrm{pH}$ to destabilize these complexes ${ }^{14 \mathrm{a}}$. In the current work, we have investigated whether endosomal $\mathrm{pH}$ also has a direct influence on cell surface levels and lipid raft association of CD1d/glycolipid complexes. Our findings confirm that neutralization of endosomal $\mathrm{pH}$ increases the cell surface levels of CD1d complexes containing Th2-biasing glycolipids, most likely by stabilizing these complexes in intracellular compartments to allow their transport to the plasma membrane. Interestingly, the stabilization of these complexes in endosomes led to their increased accumulation in plasma membrane lipid raft microdomains, and also resulted in enhanced NK transactivation. These results support a model for CD1d-mediated glycolipid presentation in which stable binding of glycolipid antigens in the endosome is the main determinant of subsequent transport to plasma membrane lipid rafts, leading to stimulation of Th1-biased iNKT cell responses. 


\section{Results}

\section{Effect of endosomal pH on CD1d expression and glycolipid presentation}

The weak bases chloroquine (CQ) and ammonium chloride $\left(\mathrm{NH}_{4} \mathrm{Cl}\right)$ have been used extensively to neutralize the $\mathrm{pH}$ of intracellular compartments such as late endosomes and lysosomes ${ }^{19}$. Using a well-defined transformed mouse dendritic cell line (JAWS II) which highly expresses CD1d as a model ${ }^{8 \mathrm{a}, 20}$, we investigated the effects of these agents on CD1d expression and antigen presentation. We chose to use $\mathrm{CQ}$ and $\mathrm{NH}_{4} \mathrm{Cl}$, which accumulate in endosomes to neutralize their $\mathrm{pH}$, rather then specific inhibitors of the vacuolar proton ATPase (e.g., Baflomycin A and D, Concanamycin A and Concanolid A), since the latter can have additional effects on cells such as disruption of vesicular transport processes ${ }^{21,22}$. Both $\mathrm{NH}_{4} \mathrm{Cl}$ and $\mathrm{CQ}$ diffuse rapidly into the lumen of endocytic vesicles and become trapped there in their protonated form, resulting in elevation of endosomal $\mathrm{pH}$, and this effect has been shown to persist for up to several hours after removal of the drug from the extracellular medium 19, 23 .

Dendritic cells are highly susceptible to changes in cell culture conditions, raising the potential concern that disruption of endosomal processing could cause cell death or alteration in the level of CD1d. We therefore tested $\mathrm{CQ}$ and $\mathrm{NH}_{4} \mathrm{Cl}$ for their effects on cell viability and CD1d expression. We cultured JAWS II cells in media containing CQ or $\mathrm{NH}_{4} \mathrm{Cl}$ for 4 hours, and then analyzed the cells for viability based on propidium iodide exclusion, and for surface expression of CD1d by staining with a CD1d-specific antibody. Treatment of these cells with either $\mathrm{CQ}$ or $\mathrm{NH}_{4} \mathrm{Cl}$ at the concentrations used did not result in alteration of CD1d expression (Figure 1), and led to only minor reductions in cell viability and no visible alteration in cell morphology (not shown).

We focused on presentation of six well-characterized iNKT cell glycolipid antigens, which are illustrated in Figure 2. The aGC C26:0 glycolipid is a potent inducer of both IFN $\gamma$ and IL-4 in vivo, and is described as a mixed (Th1 + Th2) or Th0 agonist ${ }^{8 b}$. The C-glycoside analogue a-C-GC C26:0, which stimulates much lower IL-4 and relatively higher and more prolonged IFN $\gamma$ secretion, is the prototypical Th1-biasing agonist. The other glycolipids illustrated in Figure 2 (aGC C20:2, aGC C20:1, aGC C18:3 and aGC C10:0) belong to the class of Th2-biasing agonists, which stimulate strong IL-4 secretion relative to

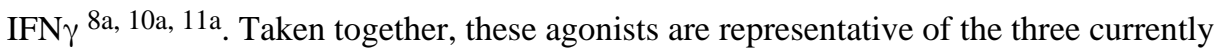
classified categories of iNKT cell activating glycolipids, which are defined mainly by the relative Th1 versus Th2 cytokine biases of the responses they induce in vivo in mice. We included multiple Th2-biaising agonists in our analyses in order to identify general mechanisms that would apply to this class of agonists despite their marked structural dissimilarities.

Endosomal acidification is crucial to many normal cellular processing, and extended treatment with agents that neutralize endosomal $\mathrm{pH}$ may be toxic or lethal. To reduce the time of exposure, we first incubated the cells with glycolipids under normal culture conditions to allow the formation of glycolipid/CD1d complexes, and then treated them for a limited time with lysosomotropic agents. Thus, JAWS II cells were cultured with each glycolipid agonist for 16 hours, followed by treatment with $\mathrm{NH}_{4} \mathrm{Cl}$ or $\mathrm{CQ}$ for an additional 
one or four hours, respectively. The efficiency of glycolipid antigen loading under these conditions was estimated by surface staining of the cells with L363, a monoclonal antibody specific for complexes formed by the binding of a GC glycolipids to mouse CD1d. A significant increase in the fluorescence intensity of cells loaded with each of the four Th2type glycolipid agonists was observed in response to treatment with either $\mathrm{CQ}$ or $\mathrm{NH}_{4} \mathrm{Cl}$. In contrast, the staining observed for the aGC C26:0 or a-C-GC treated cells was markedly reduced (Figure 3), highlighting the requirement of low endosomal $\mathrm{pH}$ for the loading of Th0 and Th1-biaising glycolipid analogues. In contrast, the increase in cell surface levels of CD1d bound with Th2-biasing glycolipids observed after $\mathrm{NH}_{4} \mathrm{Cl}$ or $\mathrm{CQ}$ treatment suggested that low $\mathrm{pH}$ is non-permissive for intracellular loading of Th2-biasing agonists onto CD1d in endosomes. Another possibility would be that the binding of the Th2-biasing glycolipids to CD1d occurs on the cell surface, and is disrupted and lost during recycling through the acidic endosomal compartment under normal conditions. In this scenario, alkalinization of endosomal $\mathrm{pH}$ would reduce the extent of unloading of Th2-biasing glycolipids from CD1d and result in an accumulation of complexes on the cell surface.

\section{Endosomal acidification and lipid raft localization of CD1d/glycolipid complexes}

Since the effects of $\mathrm{NH}_{4} \mathrm{Cl}$ and $\mathrm{CQ}$ on glycolipid presentation were similar in our initial experiments, we focused on $\mathrm{NH}_{4} \mathrm{Cl}$ for further experiments to examine the effect of inhibiting endosomal acidification on plasma membrane localization of CD1d/aGC complexes. Lipid rafts are enriched in cholesterol and contain tightly packed membrane lipids that make these microdomains resistant to extraction with low, sublytic detergent concentrations. Based on these properties, we previously developed a fluorescence-based method to estimate the lipid raft residency of cell surface CD1d/aGC complexes ${ }^{11 b}$. Since plasma membrane lipid rafts are detergent resistant, CD1d/glycolipid agonist complexes localized in lipid rafts are not extracted by exposure to $0.06 \%$ Triton X-100, and a minimal decrease in binding of fluorescent L363 antibody is observed over time. In contrast, for the CD1d/glycolipid complexes that are excluded from lipid rafts, the binding of fluorescent L363 decreases rapidly following the addition of detergent. Estimation of lipid raft residency can therefore be obtained based on the profile of decrease in L363 fluorescence after detergent exposure, with lower detergent sensitivity indicating a higher level of lipid raft occupancy.

We used this method to analyze the effect of $\mathrm{NH}_{4} \mathrm{Cl}$ treatment of JAWS II cells on the lipid raft localization of $\mathrm{CD} 1 \mathrm{~d} / \mathrm{aGC}$ complexes formed by each of the six glycolipid antigens (Figure 4). As expected based on previous studies ${ }^{11 b}$, both aGC C26:0 (Th0) and a-C-GC (Th1) loaded CD1d complexes showed high levels of lipid raft localization, and this was not significantly changed by $\mathrm{NH}_{4} \mathrm{Cl}$ treatment. In contrast, all of the Th2-biasing glycolipids showed much lower lipid raft residency. Strikingly, this was substantially increased in all four cases by $\mathrm{NH}_{4} \mathrm{Cl}$ treatment (Figure $4 \mathrm{a}$ ). Analysis of the percent of detergent resistant $\mathrm{CD} 1 \mathrm{~d} / \mathrm{aGC}$ complexes formed in the presence and absence of $\mathrm{NH}_{4} \mathrm{Cl}$ was analyzed by twoway ANOVA, which confirmed the significant increase in lipid raft localization of CD1d complexes with Th2-biasing glycolipids in cells treated with $\mathrm{NH}_{4} \mathrm{Cl}$ (Figure 4b). In addition, although there was a reduction in the number of $\mathrm{CD} 1 \mathrm{~d} / \mathrm{aGC}$ complexes formed with aGC C26:0 and a-C-GC C26:0 analogues, there was no difference observed in the lipid raft 
localization of these complexes after $\mathrm{NH}_{4} \mathrm{Cl}$ treatment. These results indicated that endosomal acidification, while not required for trafficking of CD1d/aGC complexes into lipid rafts for Th1-type glycolipids, has an inhibitory effect on the lipid raft localization of CD1d complexes containing Th2-biasing glycolipids. This inhibitory effect can be at least partially overcome by inhibition of endosomal acidification by $\mathrm{NH}_{4} \mathrm{Cl}$.

\section{Influence of endosomal acidification on NK cell transactivation}

Previous studies have demonstrated that increased lipid raft residency of CD1d molecules presenting glycolipid antigens correlates with enhanced transactivation of bystander NK cells to trigger their IFN $\gamma$ secretion ${ }^{8}$. Since it is not feasible to treat mice with sufficient amounts of lysosomotropic bases to neutralize endosomal $\mathrm{pH}$ in APCs in vivo, we developed an ex vivo approach to study the effect of neutralization of endosomal $\mathrm{pH}$ on in vivo $\mathrm{CD} 1 \mathrm{~d}-$ mediated immune responses. For this, splenic dendritic cells (DCs) were isolated from Flt-3 melanoma bearing mice as previously described ${ }^{8 b}$. The purified DCs were pulsed with aGC C20:2 in the presence or absence of CQ for four hours. These cells were then transferred to naïve animals by intravenous injection, and the levels of NK cell transactivation were assessed 16 hours later by analyzing intracellular staining for IFN $\gamma$ in splenic NK cells. As a positive control, we also transferred a-C-GC C26:0 pulsed DCs, which have been previously shown to induce NK transactivation in similar cell transfer experiments ${ }^{8 \mathrm{a}}$.

The NK cell transactivation was measured using a multiparameter flow cytometry approach to identify NK cells staining for intracellular IFN $\gamma$ as an index of transactivation, combined with a gating strategy to distinguish three different populations that express the cell surface marker NK1.1 (Figure 5a). These include a population of NK1.1 $1^{\text {Pos }} \mathrm{TCR} \beta^{\mathrm{Pos}}$ cells corresponding to NKT cells (R4), as well as the NK1.1 positive cells that lack TCR $\beta$ (R5). In addition, the R5 subset cells are further split into classic NK cells that express NKp46, and a minor fraction of cells that are NKp46 negative. Induction of IFN $\gamma$ production after injection of glycolipid loaded DCs was mainly observed in the NK1.1 ${ }^{\mathrm{Pos}} \mathrm{NKp} 46^{\mathrm{Pos}}$ subset, and this showed the expected strong NK cell transactivation with a-C-GC compared to the weak transactivation with aGC C20:2 loaded DCs. Most notably, the treatment of aGC C20:2 loaded DCs with CQ prior to transfer to mice caused a significant increase in the number of IFN $\gamma^{+}$cells detected in the $\mathrm{NKp} 46^{\mathrm{Pos}}$ subset, indicating increased $\mathrm{NK}$ cell transactivation in vivo (Figure 5b). Thus, loading of APCs with a Th2-biasing form of aGC in the presence of an inhibitor of endosomal acidification, which increases lipid raft localization of CD1d/glycolipid complexes, also correlated with increased transactivation of NK cells in vivo. We also analyzed the levels of serum IFNa at 2 hours or 12 hours post injection, but did not observe a siginificant difference in these between the animals receiving CQ treated DCs versus untreated DCs (data not shown). Typically, the transactivation of NK cells following aGalCer administration results in a sustained elevation of serum IFN $\gamma$ levels that peaks at 24 hours post glycolipid administration. Although we did not assess serum cytokine levels later than 12 hours after DC injections, the increase in NK cell transactivation that we observed would likely result in more sustained circulating IFN $\gamma$ at later time points in the mice receiving CQ treated DCs compared to untreated DC group. 


\section{Discussion}

CD1d-restricted iNKT cells are an intriguing subset of $\mathrm{T}$ cells that function at the inferface between innate and adaptive immune responses. They are important for mammalian immunity to microbial infections, and also are likely to contribute to autoimmune disorders and responses to cancers $1 \mathrm{~b}, 3 \mathrm{a}$. The ability to activate these cells by a single administration of a glycolipid agonist makes them an attractive target for development of immunotherapeutic applications $5 \mathrm{~b}$. The class of aGC analogues identified as Th1-biasing glycolipid antigens are extremely potent because of their capability to activate bystander cells and work as potent adjuvants for enhancing $\mathrm{T}$ cell priming applications such as vaccines against microbial pathogens as well as cancers ${ }^{6 a}$. On the other hand, the class of Th2-biasing glycolipid antigens are of potential interest as immunomodulators for controlling acute or chronic inflammation, and as adjuvants for enhancing antibody responses. It is therefore important to understand the detailed mechanisms that explain the structure-activity relationship for glycolipid activators of iNKT cells, which leads to their ability to mediate a wide range of different immunological outcomes.

We have previously demonstrated that Th1-biasing forms of aGC load efficiently onto CD1d only in acidified endosomal compartments, which also contain a number of lipid transport proteins that are likely to be important for this process ${ }^{8 a}, 24$. Furthermore, the association of glycolipids with CD1d in endosomes is strongly correlated with the trafficking of the resulting CD1d/glycolipid complexes to plasma membrane lipid rafts ${ }^{11 \mathrm{~b}}$. Although the mechanism accounting for the trafficking of these complexes into lipid rafts is not known, it is interesting to note that endosomal processing has also been associated with lipid raft localization of peptide-loaded MHC II complexes ${ }^{25}$. It is also noteworthy that a substantial fraction of CD1d resides in late endosomal or lysosomal compartments, which is another feature that is shared with MHC class II molecules. We therefore postulate that the intracellular loading of CD1d with Th0- and Th1-biasing glycolipids directs the newly formed complexes into trafficking pathways that lead to their localization into lipid raft domains on the plasma membrane. In contrast, the Th2-agonists that load CD1d on the cell surface do not have access to this machinery and are thus mostly excluded from the lipid rafts.

Previous studies by Bai et al. demonstrated that the uptake of both Th1-biasing and Th2biasing aGC glycolipid antigens is very similar in dendritic cells, and that both classes of glycolipids are endocytosed and delivered to acidic endosomal compartments ${ }^{14 \mathrm{~b}}$. However, their studies showed that Th2-biasing analogues were unable to form stable complexes with CD1d in endosomes. Importantly, these studies also showed that neutralization of endosomal $\mathrm{pH}$ allows the detection of $\mathrm{CD} 1 \mathrm{~d} / \mathrm{Th} 2$-biasing a GC complexes in late endosomal and lysosomal compartments. This effect of inhibition of endosomal acidification could be a result of enhanced intracellular loading of CD1d, or reduced dissociation of the glycolipid from CD1d under these conditions. In either case, this observation that neutralization of endosomal $\mathrm{pH}$ leads to the detection of $\mathrm{CD} 1 \mathrm{~d}$ with bound Th2-biasing glycolipids in endosomal compartments raised the issue of whether these complexes would be able to traffic into lipid rafts. This is the central question that we undertook to answer in the current study. 
Our studies showed that there is indeed an increase in the localization of CD1d/Th2-biasing glycolipid complexes in lipid rafts after neutralization of endosomal $\mathrm{pH}$. Localization in lipid rafts is linked with the transactivation of bystander cells such as B, T and especially NK cells. This motivated us to test if neutralization of endosomal acidity would enhance NK cell transactivation with Th2-biaisng agonists under in vivo conditions. However, administration of $\mathrm{NH}_{4} \mathrm{Cl}$ or $\mathrm{CQ}$ to rodents directly for neutralizing endosomal $\mathrm{pH}$ in vivo presents difficult challenges. For example, $\mathrm{NH}_{4} \mathrm{Cl}$ treatment in rodents induces metabolic acidosis ${ }^{26}$ and CQ administration has been shown to inhibit secretion of cytokines by $\mathrm{T}$ cells ${ }^{27}$. We therefore relied on the use of APCs pulsed with antigen ex vivo in the presence or absence of CQ to instigate the iNKT cell mediated responses following transfer into mice. One caveat of this approach is that the endosomal alkalization is reversible, and may be maintained for only a few hours after transfer of these cells into animal hosts. Nevertheless, our experiments using this method showed a modest but significant increase in NK cell transactivation when APCs were loaded in the presence of CQ with a representative Th2biasing glycolipid.

The observed increase in NK cell transactivation in response to a Th2-biasing form of aGalCer with CQ treated APCs is an important finding, given that such transactivation is a characteristic feature of Th1-biasing glycolipids. We considered the possibility that the CQ treated DCs are more stable than the untreated DCs and are therefore able to activate NK cells for longer period of time. This is unlikely given that the DCs untreated with CQ can survive at least up to 24 hours in recipient hosts ${ }^{8 \mathrm{~b}}$ and the peak of NK activation occurs at $16 \mathrm{hrs}$ post DC transfer (unpublished data). In addition, although we did not see any difference in cell viability during the ex vivo pulsing of DCs with and without CQ before transfer into recipient animals, we expect the stability of cells to be decreased rather than increased by CQ treatment since endosomal acidification is essential for normal cell survival. Furthermore, the total number of cell surface CD1d/glycolipid complexes is generally higher on APCs exposed to Th2-biasing glycolipids compared to those exposed to similar concentrations of Th1-biasing glycolipids, when measured by staining with the complex-specific L363 antibody $8 \mathrm{a}, 11 \mathrm{~b}, 14 \mathrm{~b}$ This indicates that NK cell transactivation depends on a qualitatively different initial response of iNKT cells, and not merely a difference in the quantitative strength of TCR signalling. Our previous studies have revealed that upregulation of costimulatory molecules that can directly activate NK cells is orchestrated by reciprocal interactions between APC and iNKT cells ${ }^{8 b}$. Therefore, even the small but significant increase in NK cell transactivation observed with aGC pulsed DCs after treatment with CQ suggested that the quality of immune response initiated by the Th2biasing glycolipid was altered to more closely resemble the response to a Th1-biasing glycolipid.

It is interesting to note that activation of iNKT cells is observed in infection models with several pathogenic bacterial species, including species of Salmonella, Mycobacteria, Legionella and Chlamydia. Most or all of these are intracellular bacteria that are known to block phagolysosomal fusion and reduce endosomal acidification ${ }^{28}$ Activation of iNKT cells has been demonstrated in response to infections with several of these bacteria, even though the identification of a direct iNKT activating agonist produced by them has been 
elusive ${ }^{29}$. Until recently, a-linked sphingolipids were thought to be unique to bacterial and plant species, but recent studies have shown that these glycolipids are indeed synthesized at low levels by mammalian cells and can be stimulatory for iNKT cells ${ }^{30}$. Furthermore, infection of dendritic cells with mycobacteria results in the down regulation of fatty acid amide hydrolase (FAAH), an enzyme involved in the catabolism of sphingolipids that is active under low $\mathrm{pH}$ conditions ${ }^{31}$. These observations suggest that the ability to enhance stable loading of endogenous glycolipids in the endosomal compartment may occur during infections with organisms that neutralize endosomal $\mathrm{pH}$, leading to enhanced lipid raft localization of stimulatory CD1d/glycolipid complexes. In this model, activation of NKT cells during infection may not depend on the presentation of bacterial glycolipid antigens, but could instead result from presentation of endogenous glycolipids in response to loss of endosomal acidificaion. This hypothesis can also accommodate the common immune evasion strategies used by several viruses, such as herpes simplex and human immunodeficiency viruses, that interfere with CD1d recycling pathways ${ }^{32}$. Experimental modifications that disrupt the endosomal localization and recycling of CD1d, such as the deletion of its cytoplasmic tail endosomal targeting motif ${ }^{33}$, would also be predicted to exclude $\mathrm{CD} 1 \mathrm{~d} / \mathrm{aGC}$ Th2 complexes from lipid raft microdomains, although our studies have not yet assessed this experimentally. Such a mechanism for generating or evading enhanced bystander cell activation could play an important role in recruiting and activating other immune cells during intracellular pathogen infection.

In conclusion, we have provided further evidence that low endosomal $\mathrm{pH}$ serves as a quality control checkpoint in the CD1d-dependent glycolipid antigen presentation pathway. In addition to confirming that neutralization of endosomal $\mathrm{pH}$ increases the intracellular association of Th2-biasing glycolipids to CD1d, we also show for the first time to our knowledge that this also enhances their presentation by lipid raft localized CD1d molecules. These findings provide further support for a model that explains the mechanism by which relatively subtle variations in glycolipid structure can lead to substantially different functional outcomes following iNKT cell activation.

\section{Materials and Methods}

\section{Cell lines, antibodies and cytokines}

The JAWS II cell line (derived from C57BL/6.p53-/ mice) was obtained from the American Type Culture Collection (ATCC), and was cultured in alpha-MEM medium supplemented with 20\% fetal calf serum (Atlanta Biologicals), $10 \mathrm{mM}$ HEPES, $50 \mu \mathrm{M} \beta$ mercaptoethanol, $50 \mu \mathrm{g} / \mathrm{ml}$ gentamicin, $100 \mathrm{ng} / \mathrm{ml}$ GM-CSF (Peprotech), $0.1 \mathrm{mM}$ of nonessential amino acids (NEAA) and essential amino acids (EAA) (complete aMEM). The mouse hybridoma line producing monoclonal antibody 2.4G2 specific for CD16/32 was also obtained from ATCC, and was cultured in RPMI-1640 medium supplemented with 10\% FCS, $10 \mathrm{mM}$ HEPES and $50 \mu \mathrm{M} \beta$-mercaptoethanol. All media and additives were from Gibco-BRL unless otherwise indicated. The mCD1d/aGalCer complex-specific mAb L363 was produced in our laboratory (Yu et al., 2007). Ammonium chloride (A9434) and chloroquine diphosphate (C 6628) were purchased from Sigma. 


\section{Preparation and solubilization of glycolipids}

Synthesis and analysis of the analogues of aGC used in this study have been described previously $8 \mathrm{~b}, 11 \mathrm{a}, 34$. For in vitro assays, glycolipid stock solutions were prepared at $500 \mu \mathrm{M}$ in DMSO (Sigma). Immediately before use, these stocks were heated to $70^{\circ} \mathrm{C}$, sonicated for 5 minutes and then diluted to $500 \mathrm{nM}$ in pre-warmed $\left(37^{\circ} \mathrm{C}\right.$ ) culture medium (complete aMEM). This stock was further diluted with complete aMEM culture media immediately before adding to cell cultures to give a final glycolipid concentration of $200 \mathrm{nM}$ and a final concentration of $0.04 \%$ DMSO.

\section{Estimation of CD1d/aGC complexes}

For all screening experiments, JAWS II cells were seeded at a density of $2.5 \times 10^{5}$ cells per well in $100 \mu \mathrm{l}$ culture media in flat bottom 96 well plates. Glycolipids were added to a final concentration of $200 \mathrm{nM}$. As an inert vehicle control, the cells were cultured in medium containing only $0.02 \%$ DMSO. After 16 hours of culture, the cells were detached using a cell scraper and washed 3 times with PBS containing $1 \%$ BSA and $0.1 \%$ sodium azide (wash buffer). After the final wash, the cells were resuspended in $50 \mu \mathrm{l}$ of FACS buffer (wash buffer with $1 \mu \mathrm{g} / \mathrm{ml}$ of $2.4 \mathrm{G} 2 \mathrm{mAB}$, which was added to block $\mathrm{Fc}$ receptors expressed on the surface of JAWS II cells). After 10 minutes of incubation at room temperature, $50 \mu \mathrm{l}$ of staining solution containing $5 \mu \mathrm{g} / \mathrm{ml}$ of Alexa Fluor 647 conjugated mAb L363 in FACS buffer was added to the cells. After a further 10 minutes of incubation, cells were washed thrice with wash buffer and then resuspended in $300 \mu \mathrm{l}$ wash buffer. The cells were analyzed for L363 staining using an LSR II flow cytometer with FACS Diva software (BD Biosciences).

\section{Estimation of lipid raft localization of CD1d/aGC complexes}

For estimation of lipid raft residency, the FACS analysis was performed in a kinetic mode. At the start of data acquisition, the initial fluorescence level was recorded for approximately 10 seconds. Triton X-100 was then added to a final concentration of $0.06 \%$ followed by brief $(\sim 1 \mathrm{sec})$ vortexing to mix the sample. Data collection was then resumed and fluorescence intensities were monitored for another 30 seconds. Data were collected as Flow Cytometry Standard (FCS) files and analyzed using FlowJo software vx10.07 (Treestar, Ashland, OR). MFI values at time 0 (prior to addition of Tx-100) were normalized to 100 and the relative decrease in MFI values for different agonists after addition of Tx-100 were compared.

\section{Isolation of splenic dendritic cells}

Splenic dendritic cells (DCs) were isolated using the Miltenyi CD11c-positive magnetic beads (130-152-001). The frequency of these cells in naïve murine spleen is very low, so we used a model based on the expansion of these cells in mice implanted with Flt-3 expressing melanoma cells as described previously $8 \mathrm{~b}, 35$.

\section{Adoptive transfer of glycolipid loaded dendritic cells}

Female C57BL/6 mice, 6-8 weeks of age, were injected intravenously with purified CD11c + dendritic cells pulsed with vehicle or aGalCer analogues in the presence or absence of 
CQ. For this, purified splenic DC were cultured in complete medium with $200 \mathrm{nM}$ of the indicated glycolipids for 1 hour, followed by incubation with $20 \mathrm{uM} \mathrm{CQ}$ for four hours in the groups as indicated. After extensive washing, $1 \times 10^{6}$ cells/mouse were injected into naïve mice. Animals were bled at 2 hours and 12 hours post DC transfer for measurement of serum IL-4 and IFN $\gamma$ by ELISA, and then were sacrificed sixteen hours post DC transfer for analysis of activation of NK and NKT cells.

\section{Measurement of NK cell transactivation}

Single cell suspensions of splenocytes were generated as described previously. In brief, the tissue samples were cut in approximately $10 \mathrm{~mm}^{2}$ pieces with a scalpel. The tissues pieces were digested with Liberase plus DNase, and passed through a 70 micron filter. For intracellular staining, the cells were first stained with antibodies to cell surface markers, washed three times with FACS buffer and stained with live/dead viability dye diluted in PBS, for 15 minutes at $20^{\circ} \mathrm{C}$. Excess dye was quenched by adding complete RPMI media containing $10 \%$ FCS. After extensive washing, the cells were fixed with $2 \%$ paraformaldehyde. Cells were then permeabilized with buffer containing $1 \%$ BSA, $0.1 \%$ sodium azide, $0.05 \%$ glycine and $0.05 \%$ Triton X-100 (Buffer P). Cells were blocked with $10 \%$ rat serum in buffer $P$, followed by staining for intracellular IFN $\gamma$. After washing, samples were analyzed using an LSR II flow cytometer (BD BIosciences) and Flowjo software vx10.07 (Treestar, Ashland, OR).

Statistical analysis-One way ANOVA with Dunnet's correction was used for comparing groups of three or more when there was only one independent variable. Two way ANOVA with Holm-Sidak correction was used to analyze the effect of $\mathrm{CQ}$ or $\mathrm{NH}_{4} \mathrm{Cl}$ treatment on the loading and localization of CD1d/aGC complexes as two independent factors. Statistical tests were performed using Prism 6 software (GraphPad).

\section{Acknowledgements}

This work was supported by NIH/NIAID grant AI45889 to S.A.P. C.T.J is supported by Cellular and Molecular Biology and Genetics Training Grant T32 GM007491. Flow cytometry studies were carried out using FACS core facilities supported by the Einstein Cancer Center (NIH/NCI CA013330) and Center for AIDS Research (NIH/ NIAID AI51519).

\section{References}

1. (a) Brennan PJ, Brigl M, Brenner MB. Invariant natural killer T cells: an innate activation scheme linked to diverse effector functions. Nat Rev Immunol. 2013; 13(2):101-117. [PubMed: 23334244] (b) Kronenberg M. Toward an understanding of NKT cell biology: progress and paradoxes. Annual review of immunology. 2005; 23:877-900.

2. Porcelli S, Yockey CE, Brenner MB, Balk SP. Analysis of T cell antigen receptor (TCR) expression by human peripheral blood CD4-8- alpha/beta T cells demonstrates preferential use of several V beta genes and an invariant TCR alpha chain. The Journal of experimental medicine. 1993; 178(1): 1-16. [PubMed: 8391057]

3. (a) Bendelac A, Savage PB, Teyton L. The biology of NKT cells. Annual review of immunology. 2007; 25:297-336.(b) Benlagha K, Bendelac A. CD1d-restricted mouse V alpha 14 and human V alpha 24 T cells: lymphocytes of innate immunity. Seminars in immunology. 2000; 12(6):537-542. [PubMed: 11145859] 
4. (a) Matsuda JL, Gapin L, Baron JL, Sidobre S, Stetson DB, Mohrs M, Locksley RM, Kronenberg M. Mouse V alpha 14i natural killer T cells are resistant to cytokine polarization in vivo. Proceedings of the National Academy of Sciences of the United States of America. 2003; 100(14): 8395-8400. [PubMed: 12829795] (b) Stetson DB, Mohrs M, Reinhardt RL, Baron JL, Wang ZE, Gapin L, Kronenberg M, Locksley RM. Constitutive cytokine mRNAs mark natural killer (NK) and NK T cells poised for rapid effector function. The Journal of experimental medicine. 2003; 198(7): 1069-1076. [PubMed: 14530376]

5. (a) McEwen-Smith RM, Salio M, Cerundolo V. The Regulatory Role of Invariant NKT Cells in Tumor Immunity. Cancer immunology research. 2015; 3(5):425-435. [PubMed: 25941354] (b) Yu KO, Porcelli SA. The diverse functions of CD1d-restricted NKT cells and their potential for immunotherapy. Immunology letters. 2005; 100(1):42-55. [PubMed: 16083968]

6. (a) Venkataswamy MM, Porcelli SA. Lipid and glycolipid antigens of CD1d-restricted natural killer T cells. Seminars in immunology. 2010; 22(2):68-78. [PubMed: 19945296] (b) Tashiro T. Structure-activity relationship studies of novel glycosphingolipids that stimulate natural killer Tcells. Bioscience, biotechnology, and biochemistry. 2012; 76(6):1055-1067.

7. De Libero G, Mori L. Recognition of lipid antigens by T cells. Nat Rev Immunol. 2005; 5(6):485496. [PubMed: 15928680]

8. (a) Im JS, Arora P, Bricard G, Molano A, Venkataswamy MM, Baine I, Jerud ES, Goldberg MF, Baena A, Yu KO, Ndonye RM, Howell AR, Yuan W, Cresswell P, Chang YT, Illarionov PA, Besra GS, Porcelli SA. Kinetics and cellular site of glycolipid loading control the outcome of natural killer T cell activation. Immunity. 2009; 30(6):888-898. [PubMed: 19538930] (b) Arora P, Baena A, Yu KO, Saini NK, Kharkwal SS, Goldberg MF, Kunnath-Velayudhan S, Carreno LJ, Venkataswamy MM, Kim J, Lazar-Molnar E, Lauvau G, Chang YT, Liu Z, Bittman R, Al-Shamkhani A, Cox LR, Jervis PJ, Veerapen N, Besra GS, Porcelli SA. A single subset of dendritic cells controls the cytokine bias of natural killer T cell responses to diverse glycolipid antigens. Immunity. 2014; 40(1):105-116. [PubMed: 24412610]

9. (a) Brigl M, Bry L, Kent SC, Gumperz JE, Brenner MB. Mechanism of CD1d-restricted natural killer T cell activation during microbial infection. Nat Immunol. 2003; 4(12):1230-1237. [PubMed: 14578883] (b) Carnaud C, Lee D, Donnars O, Park SH, Beavis A, Koezuka Y, Bendelac A. Cutting edge: Cross-talk between cells of the innate immune system: NKT cells rapidly activate NK cells. J Immunol. 1999; 163(9):4647-4650. [PubMed: 10528160]

10. (a) Forestier C, Takaki T, Molano A, Im JS, Baine I, Jerud ES, Illarionov P, Ndonye R, Howell AR, Santamaria P, Besra GS, Dilorenzo TP, Porcelli SA. Improved outcomes in NOD mice treated with a novel Th2 cytokine-biasing NKT cell activator. J Immunol. 2007; 178(3):1415-1425. [PubMed: 17237389] (b) Yu ED, Girardi E, Wang J, Mac TT, Yu KO, Van Calenbergh S, Porcelli SA, Zajonc DM. Structural basis for the recognition of C20:2-alphaGalCer by the invariant NKT TCR-like antibody L363. J Biol Chem. 2011(c) Oki S, Chiba A, Yamamura T, Miyake S. The clinical implication and molecular mechanism of preferential IL-4 production by modified glycolipid-stimulated NKT cells. The Journal of clinical investigation. 2004; 113(11):1631-1640. [PubMed: 15173890]

11. (a) Yu KO. Modulation of CD1d-restricted NKT cell responses by using N-acyl variants of [alpha]-galactosylceramides. Proc. Natl Acad. Sci. USA. 2005; 102:3383-3388. [PubMed: 15722411] (b) Arora P, Venkataswamy MM, Baena A, Bricard G, Li Q, Veerapen N, Ndonye R, Park JJ, Lee JH, Seo KC, Howell AR, Chang YT, Illarionov PA, Besra GS, Chung SK, Porcelli SA. A rapid fluorescence-based assay for classification of iNKT cell activating glycolipids. J Am Chem Soc. 2011; 133(14):5198-5201. [PubMed: 21425779] (c) Miyamoto K, Miyake S, Yamamura T. A synthetic glycolipid prevents autoimmune encephalomyelitis by inducing TH2 bias of natural killer T cells. Nature. 2001; 413(6855):531-534. [PubMed: 11586362]

12. Schmieg J, Yang G, Franck RW, Tsuji M. Superior protection against malaria and melanoma metastases by a C-glycoside analogue of the natural killer T cell ligand [alpha]galactosylceramide. J. Exp. Med. 2003; 198:1631-1641. [PubMed: 14657217]

13. Yu KO, Im JS, Illarionov PA, Ndonye RM, Howell AR, Besra GS, Porcelli SA. Production and characterization of monoclonal antibodies against complexes of the NKT cell ligand alphagalactosylceramide bound to mouse CD1d. J Immunol Methods. 2007; 323(1):11-23. [PubMed: 17442335] 
14. (a) Bai L, Constantinides MG, Thomas SY, Reboulet R, Meng F, Koentgen F, Teyton L, Savage PB, Bendelac A. Distinct APCs explain the cytokine bias of alpha-galactosylceramide variants in vivo. J Immunol. 2012; 188(7):3053-3061. [PubMed: 22393151] (b) Bai L, Sagiv Y, Liu Y, Freigang S, Yu KO, Teyton L, Porcelli SA, Savage PB, Bendelac A. Lysosomal recycling terminates CD1d-mediated presentation of short and polyunsaturated variants of the NKT cell lipid antigen alphaGalCer. Proceedings of the National Academy of Sciences of the United States of America. 2009; 106(25):10254-10259. [PubMed: 19506241]

15. Maxfield FR, Yamashiro DJ. Endosome acidification and the pathways of receptor-mediated endocytosis. Advances in experimental medicine and biology. 1987; 225:189-198. [PubMed: 2839960]

16. Yuan W, Qi X, Tsang P, Kang SJ, Illarionov PA, Besra GS, Gumperz J, Cresswell P. Saposin B is the dominant saposin that facilitates lipid binding to human CD1d molecules. Proceedings of the National Academy of Sciences of the United States of America. 2007; 104(13):5551-5556. [PubMed: 17372201]

17. Staubach S, Hanisch FG. Lipid rafts: signaling and sorting platforms of cells and their roles in cancer. Expert review of proteomics. 2011; 8(2):263-277. [PubMed: 21501018]

18. Keir ME, Butte MJ, Freeman GJ, Sharpe AH. PD-1 and its ligands in tolerance and immunity. Annual review of immunology. 2008; 26:677-704.

19. Ashfaq UA, Javed T, Rehman S, Nawaz Z, Riazuddin S. Lysosomotropic agents as HCV entry inhibitors. Virology journal. 2011; 8:163. [PubMed: 21481279]

20. Mackay VLSWA, Moore Emma E, Seattle WA. Immortalized dendritic cells. 1997

21. Harvey WR. Physiology of V-ATPases. The Journal of experimental biology. 1992; 172:1-17. [PubMed: 1491219]

22. Bayer N, Schober D, Prchla E, Murphy RF, Blaas D, Fuchs R. Effect of bafilomycin A1 and nocodazole on endocytic transport in HeLa cells: implications for viral uncoating and infection. Journal of virology. 1998; 72(12):9645-9655. [PubMed: 9811698]

23. (a) Hart PD, Young MR. Ammonium chloride, an inhibitor of phagosome-lysosome fusion in macrophages, concurrently induces phagosome-endosome fusion, and opens a novel pathway: studies of a pathogenic mycobacterium and a nonpathogenic yeast. The Journal of experimental medicine. 1991; 174(4):881-889. [PubMed: 1919441] (b) Chen PM, Gombart ZJ, Chen JW. Chloroquine treatment of ARPE-19 cells leads to lysosome dilation and intracellular lipid accumulation: possible implications of lysosomal dysfunction in macular degeneration. Cell \& bioscience. 2011; 1(1):10. [PubMed: 21711726]

24. Roberts TJ, Sriram V, Spence PM, Gui M, Hayakawa K, Bacik I, Bennink JR, Yewdell JW, Brutkiewicz RR. Recycling CD1d1 molecules present endogenous antigens processed in an endocytic compartment to NKT cells. J Immunol. 2002; 168(11):5409-5414. [PubMed: 12023333]

25. Buatois V, Baillet M, Becart S, Mooney N, Leserman L, Machy P. MHC class II-peptide complexes in dendritic cell lipid microdomains initiate the CD4 Th1 phenotype. J Immunol. 2003; 171(11):5812-5819. [PubMed: 14634090]

26. Nowik M, Kampik NB, Mihailova M, Eladari D, Wagner CA. Induction of metabolic acidosis with ammonium chloride $\left(\mathrm{NH}_{4} \mathrm{Cl}\right)$ in mice and rats--species differences and technical considerations. Cellular physiology and biochemistry : international journal of experimental cellular physiology, biochemistry, and pharmacology. 2010; 26(6):1059-1072.

27. Yang M, Cao L, Xie M, Yu Y, Kang R, Yang L, Zhao M, Tang D. Chloroquine inhibits HMGB1 inflammatory signaling and protects mice from lethal sepsis. Biochemical pharmacology. 2013; 86(3):410-418. [PubMed: 23707973]

28. Flannagan RS, Cosio G, Grinstein S. Antimicrobial mechanisms of phagocytes and bacterial evasion strategies. Nature reviews. Microbiology. 2009; 7(5):355-366. [PubMed: 19369951]

29. Paget $C$, Trottein F. Role of type 1 natural killer T cells in pulmonary immunity. Mucosal immunology. 2013; 6(6):1054-1067. [PubMed: 24104457]

30. (a) Brennan PJ, Tatituri RV, Heiss C, Watts GF, Hsu FF, Veerapen N, Cox LR, Azadi P, Besra GS, Brenner MB. Activation of iNKT cells by a distinct constituent of the endogenous glucosylceramide fraction. Proceedings of the National Academy of Sciences of the United States 
of America. 2014; 111(37):13433-13438. [PubMed: 25197085] (b) Kain L, Webb B, Anderson BL, Deng S, Holt M, Costanzo A, Zhao M, Self K, Teyton A, Everett C, Kronenberg M, Zajonc DM, Bendelac A, Savage PB, Teyton L. The identification of the endogenous ligands of natural killer T cells reveals the presence of mammalian alpha-linked glycosylceramides. Immunity. 2014; 41(4):543-554. [PubMed: 25367571]

31. Freigang S, Zadorozhny V, McKinney MK, Krebs P, Herro R, Pawlak J, Kain L, Schrantz N, Masuda K, Liu Y, Savage PB, Bendelac A, Cravatt BF, Teyton L. Fatty acid amide hydrolase shapes NKT cell responses by influencing the serum transport of lipid antigen in mice. The Journal of clinical investigation. 2010; 120(6):1873-1884. [PubMed: 20484813]

32. (a) Yuan W, Dasgupta A, Cresswell P. Herpes simplex virus evades natural killer T cell recognition by suppressing CD1d recycling. Nat Immunol. 2006; 7(8):835-842. [PubMed: 16845396] (b) Horst D, Geerdink RJ, Gram AM, Stoppelenburg AJ, Ressing ME. Hiding lipid presentation: viral interference with CD1d-restricted invariant natural killer T (iNKT) cell activation. Viruses. 2012; 4(10):2379-2399. [PubMed: 23202469]

33. Lawton AP, Prigozy TI, Brossay L, Pei B, Khurana A, Martin D, Zhu T, Spate K, Ozga M, Honing S, Bakke O, Kronenberg M. The mouse CD1d cytoplasmic tail mediates CD1d trafficking and antigen presentation by adaptor protein 3-dependent and -independent mechanisms. J Immunol. 2005; 174(6):3179-3186. [PubMed: 15749847]

34. Fujii S, Shimizu K, Hemmi H, Fukui M, Bonito AJ, Chen G, Franck RW, Tsuji M, Steinman RM. Glycolipid alpha-C-galactosylceramide is a distinct inducer of dendritic cell function during innate and adaptive immune responses of mice. Proceedings of the National Academy of Sciences of the United States of America. 2006; 103(30):11252-11257. [PubMed: 16844772]

35. Arora P, Kharkwal SS, Porcelli SA. Isolation and in vivo Transfer of Antigen Presenting Cells. Bio-protocol. 2014; 4(19):e1260. 


\section{Highlights}

- Neutralization of endosomal $\mathrm{pH}$ increases presentation of Th2-biasing aGC analogues, and their association with CD1d in cholesterol rich "lipid raft" microdomains

- Pulsing the antigen presenting cells with aGC Th2-agonist in the presence of chloroquine induces higher NK cell transactivation 
a

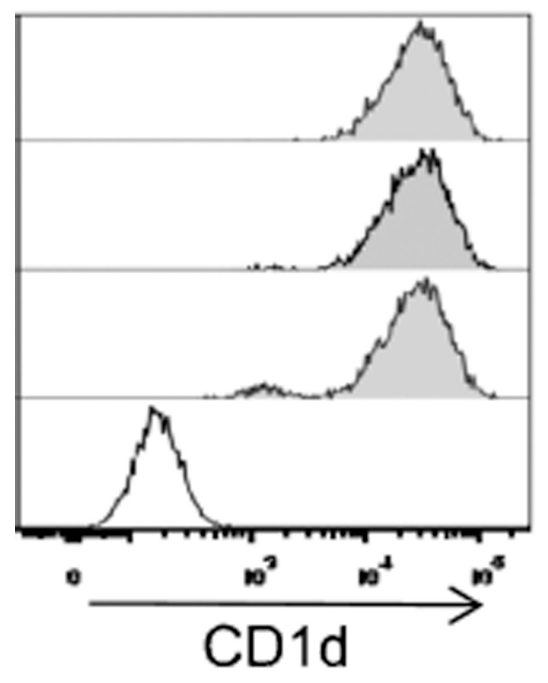

b

\section{Untreated}

$\mathrm{NH}_{4} \mathrm{Cl}$

$\mathrm{CQ}$

Isotype

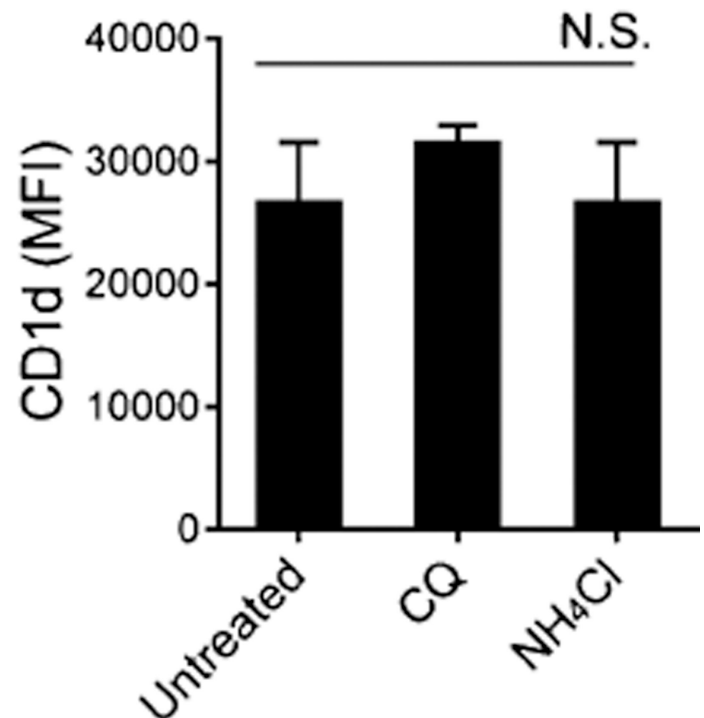

Figure 1. Effect of inhibitors of endosomal acidification on CD1d expression JAWS II cells were incubated with either ammonium chloride $\left(\mathrm{NH}_{4} \mathrm{Cl}, 10 \mathrm{mM}\right)$ for one hour, chloroquine diphosphate (CQ, $20 \mathrm{uM}$ ) for 4 hours or with medium only, following which cells were stained with anti-CD1d antibody (1B1) conjugated to FITC or a similarly labeled isotype control antibody. Cells were then analyzed by flow cytometry. Histograms showing the fluorescence intensities corresponding to CD1d expression are shown in grey, with various treatments of the cells indicated on the right. The white histogram at the bottom is the background fluorescence profile of JAWS II cells stained with the isotype control antibody. (b) The bar graphs show the median fluorescent intensity as mean \pm SD for triplicate samples. The data were analyzed by one-way ANOVA using Graphpad Prism (NS, not significant, $P>0.05)$. 

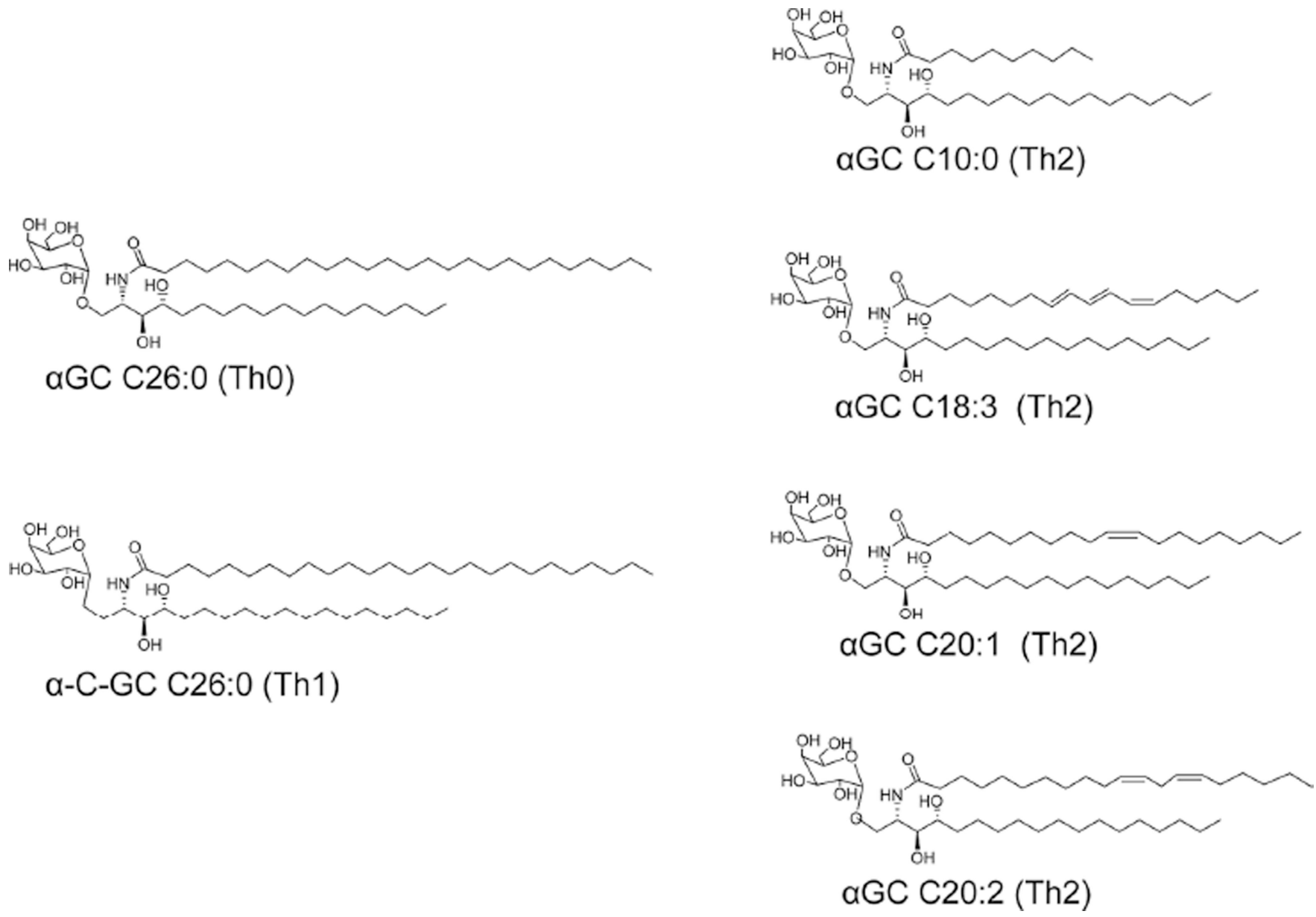

Figure 2. Chemical structures of the glycolipids used in this study

All of these aGC analogues have been previously characterized as iNKT cell activators (see text for references). 
a
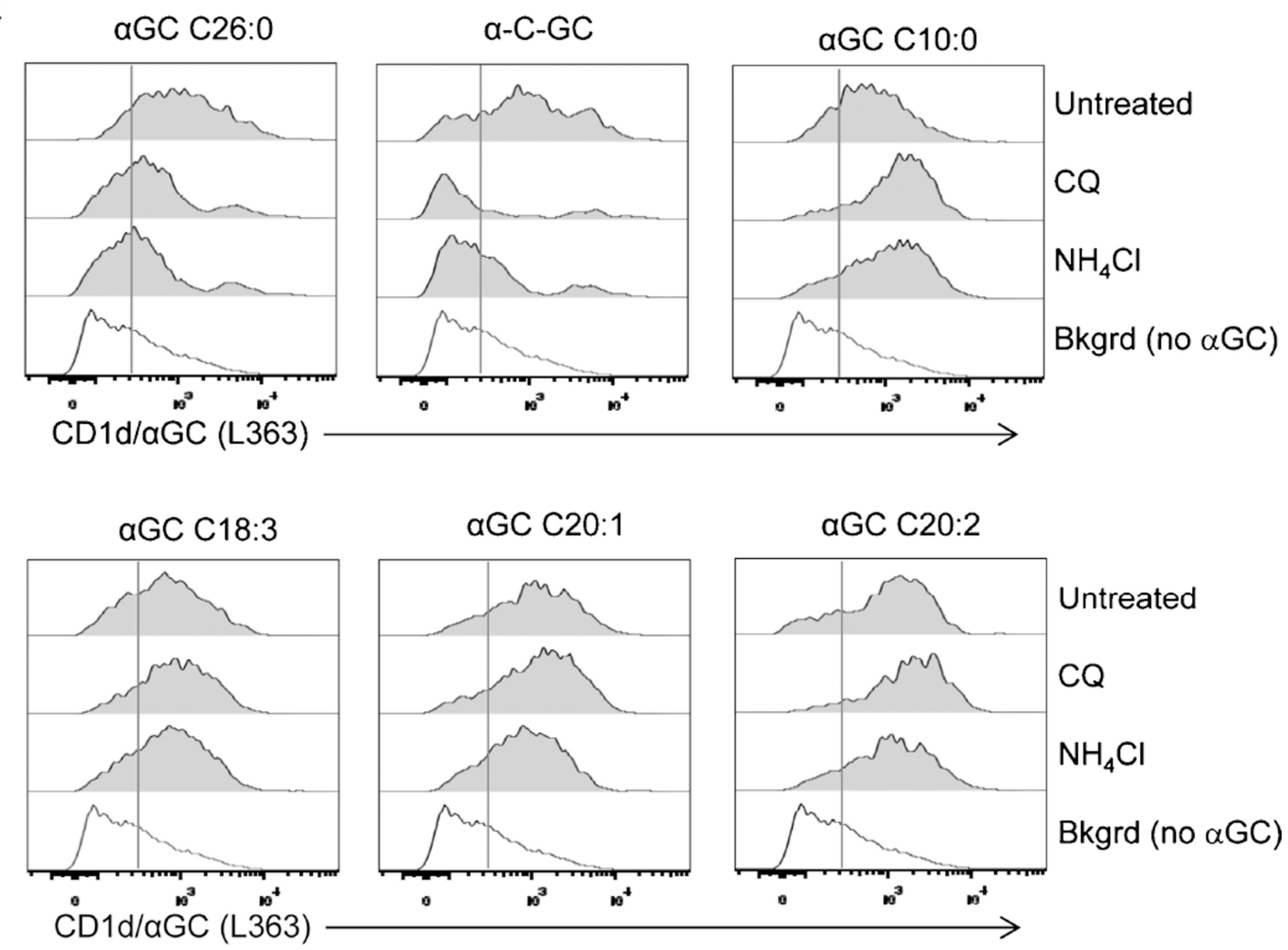

b

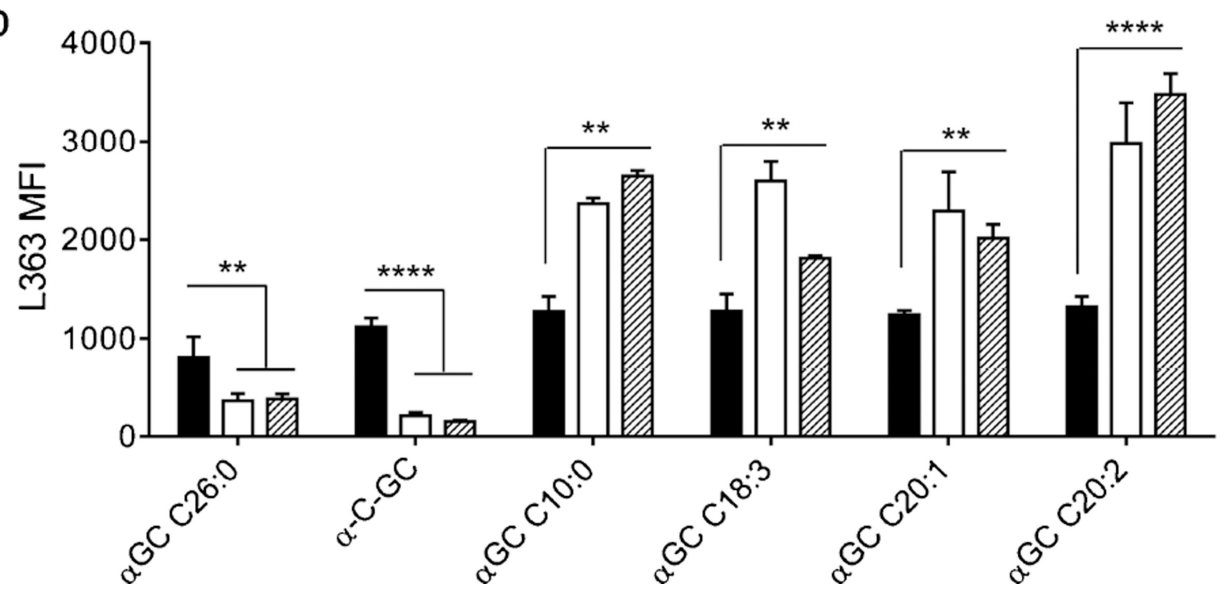

Figure 3. Effect of neutralization of endosomal $\mathrm{pH}$ on CD1d loading with aGC agonists

(a) JAWS II cells were incubated with $200 \mathrm{nM}$ of various aGC agonists for 16 hours. After washing to remove unbound glycolipid, the cells were further incubated with $\mathrm{CQ}$ or $\mathrm{NH}_{4} \mathrm{Cl}$ as in Figure 2, and stained with monoclonal antibody L363 specific for CD1d/aGC analogue complexes. The cells were then analyzed by flow cytometry. Fluorescence histograms show the effect of different treatments (as labeled on the right hand side) on L363 staining levels. The bottom histogram shows the background staining with L363 (Bkgrd) of JAWS II cells cultured without aGC or either of the inhibitors of endosomal acidification. (b) Median 
fluorescent intensities of L363 staining for CD1d/aGC complexes observed with individual glycolipid agonists with or without treatment with $\mathrm{CQ}$ or $\mathrm{NH}_{4} \mathrm{Cl}$. The black bars correspond to the standard culture conditions without inhibitors of endosomal acidification, while white and grey bars correspond to cells treated with $\mathrm{CQ}$ and $\mathrm{NH}_{4} \mathrm{Cl}$ respectively. Data is mean \pm SD for triplicate samples and was analyzed by two way ANOVA with the glycolipid agonists and endosomal acidification inhibitors as independent variables. Effect of CQ and $\mathrm{NH}_{4} \mathrm{Cl}$ treatment are highly significant for all the glycolipids tested (** $P<0.01$ and $* * * * P$ $<0.001)$. 
a

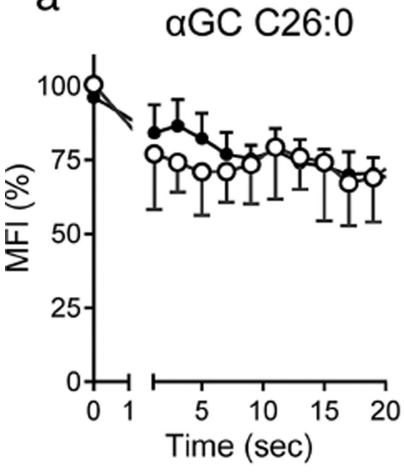

aGC C18:3

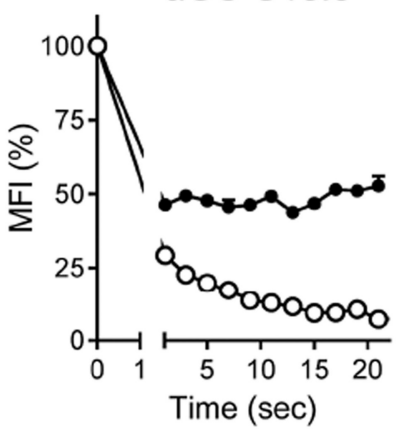

a-C-GC

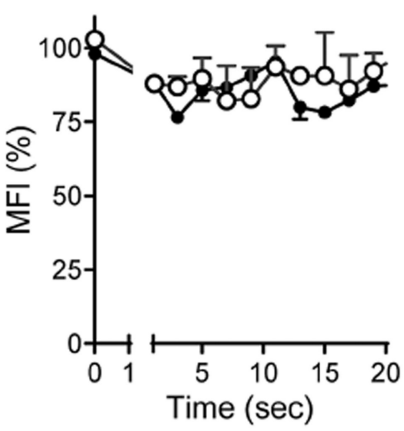

aGC C20:1

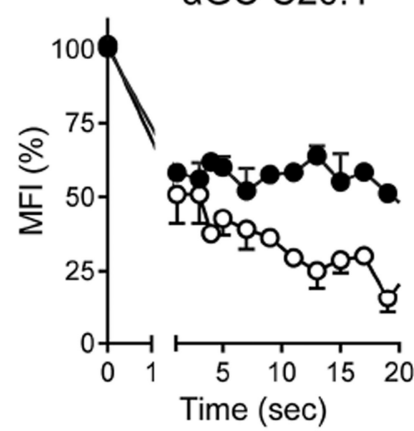

aGC C10:0
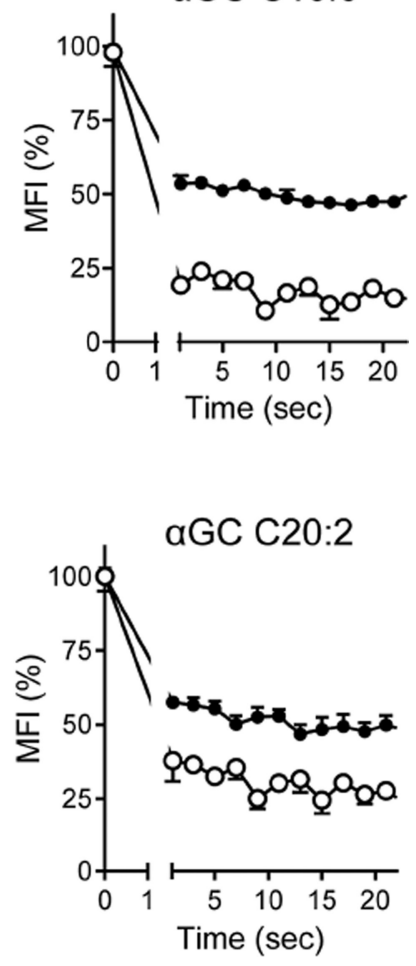

b

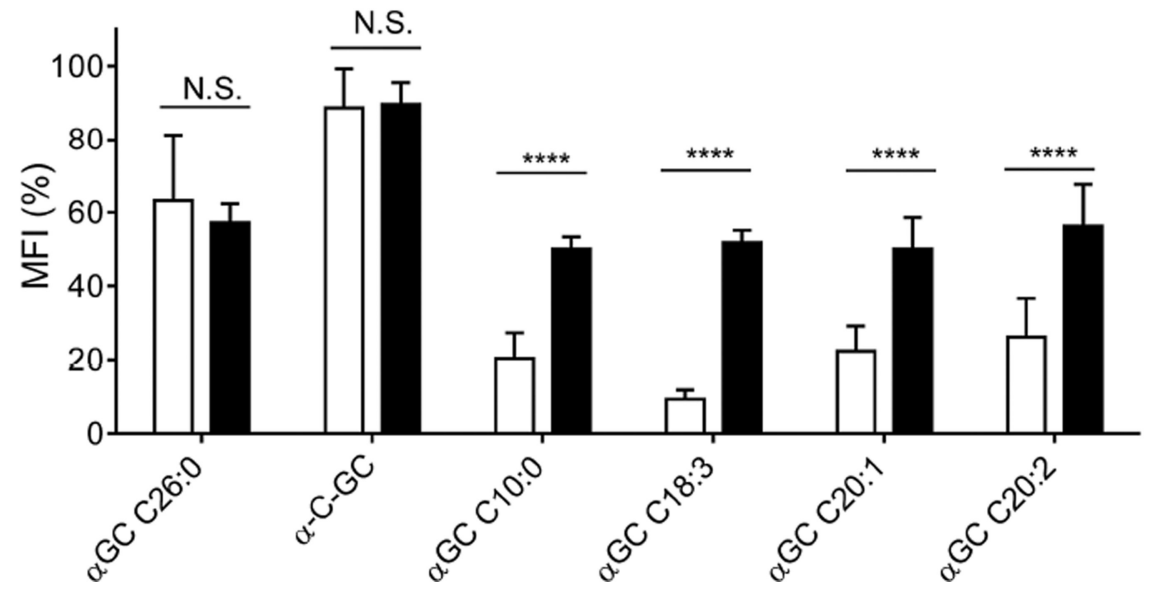

Figure 4. Effect of ammonium chloride on the lipid raft localization of CD1d and CD1d/aGC complexes

JAWS II cells were incubated with $200 \mathrm{nM}$ of various aGC agonists for 16 hours, and then harvested and washed to remove unbound glycolipid. The cells were then incubated at $37^{\circ} \mathrm{C}$ for 1 hour in culture media with or without $10 \mathrm{mM} \mathrm{NH}_{4} \mathrm{Cl}$, and then stained with fluorescent L363 antibody. Analysis of L363 binding and its detergent sensitivity was carried out by flow cytometry using the kinetic mode for data acquisition. (a) Plots show the initial level of fluorescence at time 0 (mean fluorescence intensity (MFI) normalized to $100 \%$ ), and the change in fluorescence relative to the starting level (expressed as percent of initial MFI) 
over time following addition of detergent $(0.06 \%$ Triton $\mathrm{X}-100$, addition indicated by the break in the $\mathrm{X}$-axis). Solid symbols represent cells cultured in medium with $10 \mathrm{mM} \mathrm{NH}_{4} \mathrm{Cl}$, and open symbols are medium without $\mathrm{NH}_{4} \mathrm{Cl}$. Symbols are mean values from three replicates, and error bars are $1 \mathrm{SD}$. (b) Bar graph showing the residual detergent resistant L363 binding (percent of starting MFI) at 20 seconds after addition of detergent for cells incubated with (filled bars) or without (open bars) $10 \mathrm{mM} \mathrm{NH}_{4} \mathrm{Cl}$. Data shown are means of 3 replicate values and error bars show $1 \mathrm{SD}$. $* * * * P<0.001$ (two way ANOVA). 


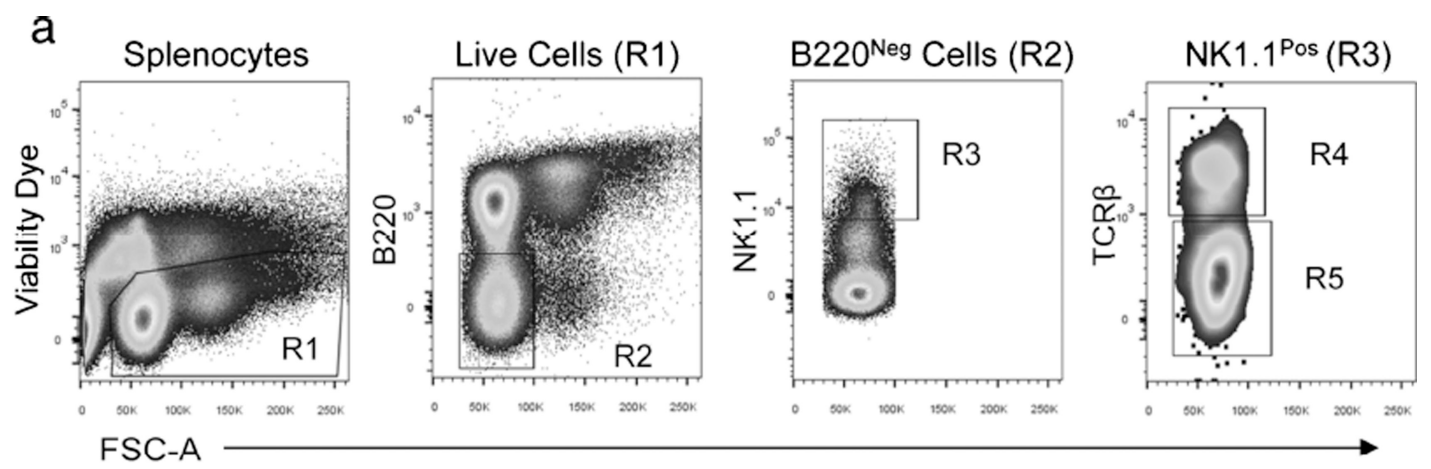

Gated on TCR $\beta^{\text {Neg NK1. }} 1^{\text {Pos }}$ Cells (R5):

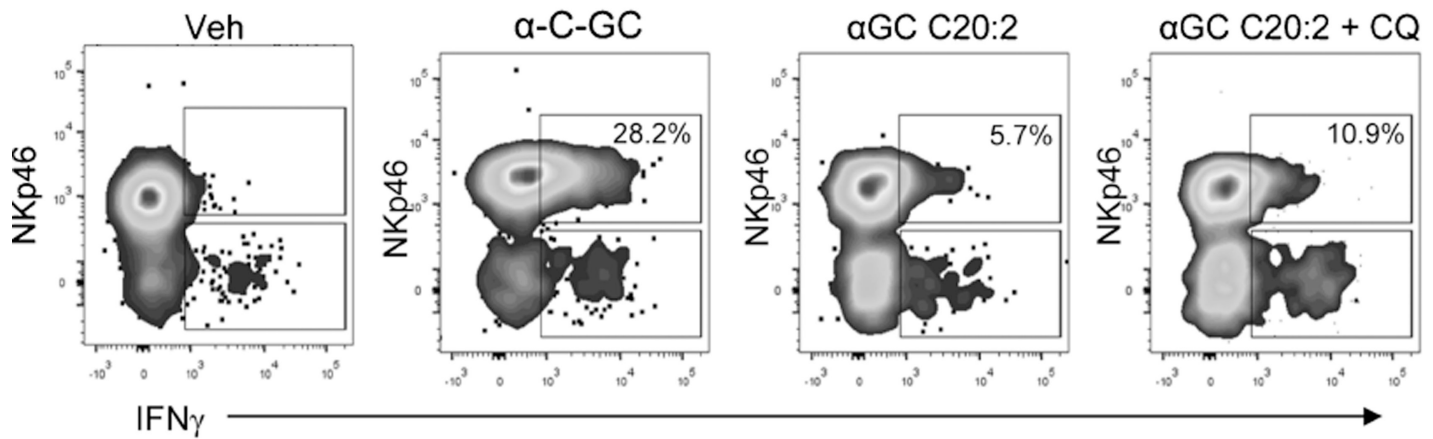

b

NK1.1 $1^{\text {Pos }}$ NKp46 Pos
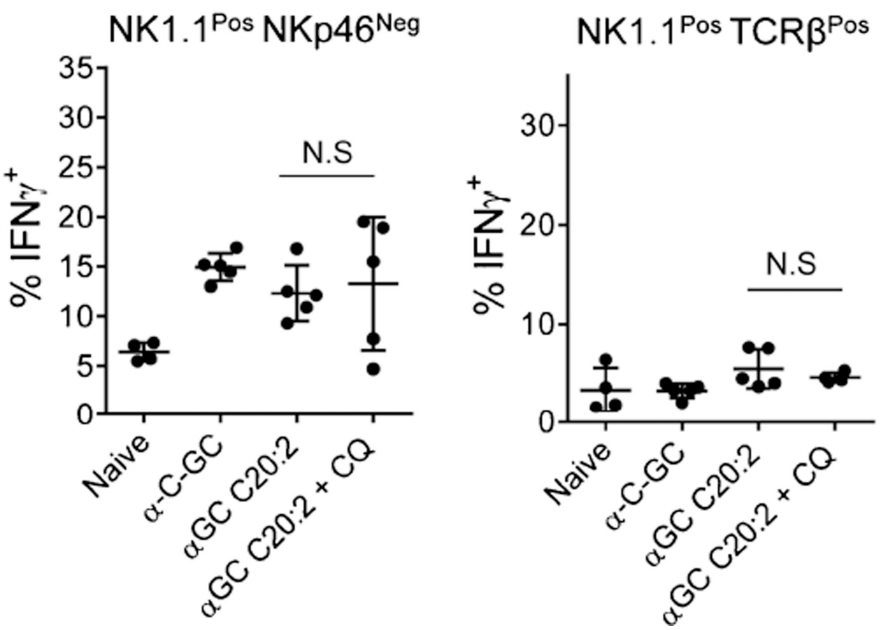

Figure 5. Effect of endosomal Alkanization on NK transactivation

Splenic DCs were pulsed with medium containing inert vehicle (Veh) or with $200 \mathrm{nM}$ of aC-GC C26:0, aGC C20:2 or aGC C20:2 plus $20 \mu \mathrm{M}$ chloroquine for four hours. These were then injected intravenously into mice, and the frequency of splenic NK1.1 positive cells producing IFN $\gamma$ was analyzed by intracellular staining using flow cytometry. (a) Representative plots show the gating strategy used to identify NK and NKT cells. Viable cells (R1) were gated to exclude B220 ${ }^{\text {Pos }}$ cells, and the B220 ${ }^{\mathrm{Neg}}$ cells (R2) were gated for NK1.1 ${ }^{\text {Pos }}$ events (R3). These were further gated for TCR $\beta$, and gated for NK1.1 TCR $\beta$ 
double positive as NKT cells (R4). The TCR $\beta^{\mathrm{Neg}}$ (R5) events were analyzed for expression of NKp46 and IFN $\gamma$. (b) Scatter plots show mean \pm SD for frequencies of IFN $\gamma$ positive cells for the various cell populations in groups of 5 mice (NS, not significant, $* * P<0.01$, one way ANOVA). 